\title{
Circadian clock protein CRY1 prevents paclitaxel-induced senescence of bladder cancer cells by promoting p53 degradation
}

\author{
MIN JIA ${ }^{1,2}$, BIJIA SU ${ }^{1,2}$, LIJUN MO ${ }^{1,2}$, WEN QIU ${ }^{2}$, JIAXU YING ${ }^{2}$, PENG LIN $^{2}$, BINGXUAN YANG $^{3}$, \\ DANYING LI ${ }^{2}$, DONGXIA WANG ${ }^{2}$, LILI XU $^{2}$, HONGWEI LI $^{2}$, ZHONGXIN ZHOU ${ }^{4}$, XING LI $^{1,5}$ and JINLONG LI ${ }^{1,2}$ \\ ${ }^{1}$ Shenzhen Ruipuxun Academy for Stem Cell and Regenerative Medicine, Shenzhen, Guangdong 518122; \\ ${ }^{2}$ Institute of Biotherapy, School of Laboratory Medicine and Biotechnology, Southern Medical University, Guangzhou, \\ Guangdong 510515; ${ }^{3}$ The Third Clinical Medical College, Guangzhou University of Chinese Medicine, \\ Guangzhou, Guangdong 510006; ${ }^{4}$ Department of Vascular Surgery, The Third Affiliated Hospital, \\ Southern Medical University; ${ }^{5}$ Department of Medical Oncology and Guangdong Key Laboratory of Liver Disease Research, \\ The Third Affiliated Hospital of Sun Yat-sen University, Guangzhou, Guangdong 510630, P.R. China
}

Received April 8, 2020; Accepted October 6, 2020

DOI: 10.3892/or.2020.7914

\begin{abstract}
Bladder cancer is a common tumor type of the urinary system, which has high levels of morbidity and mortality. The first-line treatment is cisplatin-based combination chemotherapy, but a significant proportion of patients relapse due to the development of drug resistance. Therapy-induced senescence can act as a 'back-up' response to chemotherapy in cancer types that are resistant to apoptosis-based anticancer therapies. The circadian clock serves an important role in drug resistance and cellular senescence. The aim of the present study was to investigate the regulatory effect of the circadian clock on paclitaxel (PTX)-induced senescence in cisplatin-resistant bladder cancer cells. Cisplatin-resistant bladder cancer cells were established via long-term cisplatin incubation. PTX induced apparent senescence in bladder cancer cells as demonstrated via SA- $\beta$-Gal staining, but this was not observed in the cisplatin-resistant cells. The cisplatin-resistant cells entered into a quiescent state with prolonged circadian rhythm under acute PTX stress. It was identified that the circadian protein cryptochrome1 (CRY1) accumulated in these quiescent cisplatin-resistant cells, and that CRY1 knockdown restored PTX-induced senescence. Mechanistically, CRY1 promoted p53 degradation via increasing the binding of p53 with its ubiquitin E3 ligase MDM2 proto-oncogene. These data suggested that the accumulated CRY1 in cisplatin-resistant
\end{abstract}

Correspondence to: Professor Jinlong Li or Dr Xing Li, Shenzhen Ruipuxun Academy for Stem Cell and Regenerative Medicine, 14 Jinhui Road, Shenzhen, Guangdong 518122, P.R. China

E-mail: lijinlong@smu.edu.cn

E-mail: lixing9@mail.sysu.edu.cn

Key words: circadian rhythm, cryptochrome 1, paclitaxel-induced senescence, p53 cells could prevent PTX-induced senescence by promoting p53 degradation.

\section{Introduction}

Bladdercancer (BC) is the most frequent neoplasm of the urinary tract (1). At diagnosis, $75 \%$ of cases are non-muscle-invasive $\mathrm{BC}$, while $25 \%$ of cases present with muscle-invasive BC (2). The first-line treatment is cisplatin-containing combination chemotherapy such as gemcitabine plus cisplatin or methotrexate, vinblastine, doxorubicin and cisplatin $(2,3)$. Paclitaxel (PTX) has been recently reported to be effective in inhibiting BC (4-6). Clinical trials have revealed that PTX combined with radiation (7) or gemcitabine (8) are effective treatment strategies for patients with BC, indicating that PTX is a promising second-line treatment option for patients with metastatic BC. However, a significant proportion of patients will relapse due to development of drug resistance to the chemotherapeutic regimens $(9,10)$.

Cellular senescence is irreversible cell cycle arrest in response to various forms of cellular stresses (11). In contrast to the well-studied replicative senescence of somatic cells, therapeutic implications and mechanisms of senescence in cancer treatment remain elusive (12). Currently, it is generally accepted that senescence is a tumor-suppressive mechanism, which restricts the unlimited cell proliferation, thus preventing the occurrence and development of cancer (13). Cancer cells may undergo senescence in response to ionizing radiation or chemotherapy, known as therapy-induced senescence (TIS) (14). Moreover, TIS may act as a 'back-up' response to cancer therapy, in which apoptotic pathways are disabled $(14,15)$. PTX has been reported to induce senescence of breast cancer cells $(16,17)$. However, to the best of our knowledge, TIS has not yet been reported in BC.

The circadian clock is an intrinsic timekeeping system that regulates multiple vital physiological and biochemical processes, including cell proliferation and senescence $(18,19)$. The core clock genes include circadian locomotor output 
cycles kaput (CLOCK), brain and muscle Arnt-like protein 1 (BMAL1), period (PER)1/2 and cryptochrome (CRY)1/2, which constitute a transcriptional auto-regulatory feedback loop (20). Disruption of the circadian clock can increase cancer risk in humans, but the effect of each of the four core circadian genes on tumor is not always consistent in tumors from different human organs (21-23). Furthermore, the relationship between the circadian clock and drug resistance is yet to be fully understood. The present study aimed to investigate the circadian clock in cisplatin-resistant (Res) BC cells and to examine the regulatory effect of clock genes on PTX-induced senescence.

\section{Materials and methods}

Cell culture and drug treatment. Human BC UMUC3 and EJ cell lines were purchased from the American Type Culture Collection (ATCC). EJ cells were authenticated by highresolution small tandem repeat profiling and were confirmed mycoplasma-free before experiments began. Cells were cultured in DMEM (Gibco; Thermo Fisher Scientific, Inc.) supplemented with $10 \%$ FBS (Gibco; Thermo Fisher Scientific, Inc.), penicillin $(100 \mathrm{U} / \mathrm{ml})$ and streptomycin $(100 \mu \mathrm{g} / \mathrm{ml})$, at $37^{\circ} \mathrm{C}$ in a balanced air humidified incubator with an atmosphere of $5 \%$ $\mathrm{CO}_{2}$. Res cell lines were established via long term incubation (2 months) at $37^{\circ} \mathrm{C}$ with increasing concentration of cisplatin (Sigma-Aldrich; Merck KGaA) in a range of $0-4 \mu \mathrm{g} / \mathrm{ml}$, and then were steadily grown in the presence of $2 \mu \mathrm{g} / \mathrm{ml}$ cisplatin. For PTX treatment, the Res cells or the parental UMUC3 and EJ cells were treated with 80 or 40 nM PTX (Sigma-Aldrich; Merck KGaA), respectively, for 3 days. For serum-starvation, cells were treated with serum-free medium for $48 \mathrm{~h}$ and then synchronized with $0.1 \mu \mathrm{M}$ dexamethasone for $2 \mathrm{~h}$ to examine the circadian rhythm. Cells were incubated with serum-free medium for 24,48 and $72 \mathrm{~h}$, and the circadian proteins were examined via western blotting.

Cell synchronization. Cells were synchronized in circadian time via aspiration of media and replacement with fresh DMEM containing $0.1 \mu \mathrm{M}$ dexamethasone (Sigma-Aldrich; Merck $\mathrm{KGaA}$ ). The cells were synchronized for $2 \mathrm{~h}$ at $37^{\circ} \mathrm{C}$, followed by replacing with fresh medium (circadian time $0 ; \mathrm{ZT} 0$ ). The cells did not receive any further medium changes from this point until the time of harvest. Individual plates were harvested for total RNA at ZT0,ZT4, ZT8, ZT12, ZT16,ZT20,ZT24,ZT28, ZT32, ZT36, ZT40, ZT44 and ZT48. Statistical analysis was cosine fitted using OriginPro 8.0 (https://www.originlab.com/).

Flow cytometry. For cell cycle analysis, cells were fixed in $70 \%$ ethanol overnight at $4^{\circ} \mathrm{C}$ and then were washed twice with ice-cold PBS. Cells were stained with PI staining solution $(50 \mu \mathrm{g} / \mathrm{ml} \mathrm{PI,} 100 \mu \mathrm{g} / \mathrm{ml}$ RNase, $0.05 \%$ Triton X-100 in $\mathrm{ddH} 2 \mathrm{O}$ ) at room temperature for 20-30 min. PI-stained cells were analyzed for their DNA content using FACSCalibur flow cytometer (BD Biosciences) and the data analyzed using FlowJo 7.6 (www.flowjo.com).

Cellular apoptosis was measured using the Annexin V-FITC Apoptosis Detection kit (Invitrogen; Thermo Fisher Scientific, Inc.). Briefly, $1 \times 10^{5}$ cells were resuspended in Annexin $\mathrm{V}$ binding buffer and stained with Annexin V-FITC and PI $(1 \mu \mathrm{g} / \mathrm{ml})$ at room temperature for $15 \mathrm{~min}$. The apoptotic rate was quantified via FACSCalibur flow cytometer (BD Biosciences) and the data analyzed using FlowJo 7.6 (www.flowjo.com).

MTS assay. To assess cell viability, the cells were seeded $\left(5 \times 10^{3}\right.$ cells/well) into 96 -well plates and incubated at $37^{\circ} \mathrm{C}$ with $5 \% \mathrm{CO}_{2}$ for $24 \mathrm{~h}$. Then, the cells were treated with increasing concentration of cisplatin $(0-40 \mu \mathrm{g} / \mathrm{ml})$ or PTX $(0-1,000 \mathrm{nM})$ for $48 \mathrm{~h}$ at $37^{\circ} \mathrm{C}$. After incubation, $20 \mu \mathrm{l}$ MTS solution was added into each well and incubated for $2 \mathrm{~h}$ at $37^{\circ} \mathrm{C}$. The number of viable cells was evaluated by measuring the absorbance at $490 \mathrm{~nm}$ with a microplate reader (Thermo Fisher Scientific, Inc.). In total $\geq 3$ independent experiments were conducted.

Reverse transcription-quantitative PCR (RT-qPCR). Total RNA was extracted from cells with TRIzol ${ }^{\circledR}$ reagent (Takara Biotechnology Co., Ltd.) according to the manufacturer's protocol. cDNA was synthesized with PrimeScript ${ }^{\mathrm{TM}}$ RT Master mix (Takara Biotechnology Co., Ltd.) for $15 \mathrm{~min}$ at $37^{\circ} \mathrm{C}$, and then the reverse transcriptase was inactivated for $5 \mathrm{sec}$ at $85^{\circ} \mathrm{C}$. qPCR was performed with $\mathrm{SYBR}^{\circledR}$ Premix Ex Taq ${ }^{\mathrm{TM}}$ II (Tli RNaseH Plus; Takara Biotechnology Co., Ltd.) with the following conditions in an Applied Biosystems instrument: Initial denaturation at $95^{\circ} \mathrm{C}$ for $30 \mathrm{sec}$, followed by 40 cycles of $95^{\circ} \mathrm{C}$ for $10 \mathrm{sec}, 60^{\circ} \mathrm{C}$ for $5 \mathrm{sec}$ and $72^{\circ} \mathrm{C}$ for $15 \mathrm{sec}, 95^{\circ} \mathrm{C}$ for $15 \mathrm{sec}, 60^{\circ} \mathrm{C}$ for $60 \mathrm{sec}$. The samples were quantified with $2^{-\Delta \Delta \mathrm{Cq}}$ method and $\beta$-actin was used as internal reference (24). The following primers were used: BMAL1 forward, 5'-TGC AACGCAATGTCCAGGAA-3' and reverse, 5'-GGTGGC ACCTCTTAATGTTTTCA-3'; CLOCK forward, 5'-TGC GAGGAACAATAGACCCAA-3' and reverse, 5'-ATGGCC TATGTGTGCGTTGTA-3'; CRY1 forward, 5'-TTGGAAAGG AACGAGACGCAG-3' and reverse, 5'-CGGTTGTCCACC ATTGAGTT-3'; PER2 forward, 5'-GACATGAGACCAACG AAAACTGC-3' and reverse, 5'-AGGCTAAAGGTATCTGGA CTCTG-3'; $\beta$-Actin forward, 5'-CATGTACGTTGCTATCCA GGC-3' and reverse, 5'-CTCCTTAATGTCACGCACGAT-3'; and p53 forward, 5'-CAGCACATGACGGAGGTTGT-3' and reverse 5'-TCATCCAAATACTCCACACGC-3'.

Western blotting. Total proteins from cells were extracted with RIPA lysis buffer containing $1 \mathrm{mM}$ PMSF (Fude: http://www. fdbio.net) and phosphatase inhibitor (Fude). Protein concentration was measured using a BCA Protein Assay kit (CWBio: http://www.cwbiotech.bioon.com.cn). The proteins (50 $\mu \mathrm{g} / \mathrm{lane})$ were loaded on $10 \%$ SDS-PAGE and separated by electrophoresis, followed by blotting on a PVDF membrane (EMD Millipore). The membrane was blocked in Tris-buffered saline (pH 8.0)+0.1\% Tween-20 and 5\% skim milk at room temperature for $2 \mathrm{~h}$. The corresponding primary antibody $(1: 1,000)$ was incubated overnight at $4^{\circ} \mathrm{C}$ and then incubated with the horseradish peroxide-conjugated secondary antibody (Fude; 1:10,000) at room temperature for $1 \mathrm{~h}$. Immunological signals were detected using an electrochemical luminescence kit (Yeasen; www.yeasen.com). The band intensities were quantified using Image-Pro-Plus 6.0 software (MediaCybernetics, Inc.). The primary antibodies are as follows: CRY1 (cat. no. ab245564; Abcam), PER2 (cat. no. ab179813; Abcam), CLOCK (cat. no. 18094-1-AP; ProteinTech Group, Inc.), BMAL1 (cat. no. 14268-1-AP; ProteinTech Group, Inc.), p53 (cat. no. 2524; 
Cell Signaling Technology, Inc.), p21 (cat. no. 10355-1-AP; ProteinTech Group, Inc.) and GAPDH (cat. no. AP0063; Biogot Technology Co., Ltd.).

5-Ethynyl-2'-deoxyuridine (EdU) incorporation assays. Cell proliferation was detected with a EdU labeling/detection kit (Guangzhou RiboBio Co., Ltd.). Cells were plated in 24-well plates $\left(1 \times 10^{5}\right.$ cells/well). EdU labeling medium $(1: 1,000)$ was added into wells and incubated for $2 \mathrm{~h}$ at $37^{\circ} \mathrm{C}$ according to the manufacturer's instructions. After EdU staining, cells were counterstained with Hoechst 33342 for 30 min at room temperature. The percentage of $\mathrm{EdU}^{+}$cells was calculated from five random fields each in three wells via fluorescence microscopy (magnification, $\mathrm{x} 400$; Nikon Corporation).

Small interfering RNA (siRNA) transfection. Cryl-targeting siRNAs (si-Cry1-1, 5'-GATGCAGATTGGAGCATAA-3'; and si-Cryl-2, 5'-GGATGAAACAGATCTATCA-3') were designed by Guangzhou RiboBio Co., Ltd. Cells $\left(5 \times 10^{5}\right)$ were seeded into 6-well plates and then were transfected with $100 \mathrm{nMCry} 1$ siRNA at $37^{\circ} \mathrm{C}$ for 24 or $48 \mathrm{~h}$ using Lipofectamine 2000 (Invitrogen; Thermo Fisher Scientific, Inc.) according to the manufacturer's instructions. Non-targeting siRNA was used as control.

Senescence-associated $\beta$-galactosidase (SA- $\beta$-Gal) cell staining. Senescent cells were detected using the SA- $\beta-$ Gal staining kit according to the manufacturer's instruction (Cell Signaling Technology, Inc.). Cells were washed with PBS and fixed with $4 \%$ paraformaldehyde at room temperature for $15 \mathrm{~min}$. Each well (6-well plates) was filled with $1 \mathrm{ml} \beta$-Gal staining solution. The plate was sealed with a parafilm and incubated at $37^{\circ} \mathrm{C}$ overnight in a dry incubator $\left(\right.$ no $\left.\mathrm{CO}_{2}\right)$. The percentage of SA- $\beta$-Gal-positive cells were identified as bluish green-stained cells under a fluorescent microscope (magnification, x400; Nikon Corporation).

Co-immunoprecipitation (Co-IP). After washing in cold PBS, cells were lysed with RIPA lysis buffer containing $1 \mathrm{mM}$ PMSF (Fude) and phosphatase inhibitor (Fude). Total cell lysates $(1.0 \mathrm{ml})$ were incubated with $1 \mu \mathrm{g}$ anti-p53 (cat. no. 2524; Cell Signaling Technology, Inc.) overnight at $4^{\circ} \mathrm{C}$, and then mixed with $40 \mu \mathrm{l}$ protein-A $+\mathrm{G}$ conjugated beads (Beyotime Institute of Biotechnology) to each sample. Centrifuged at $4^{\circ} \mathrm{C}$ for $14,000 \mathrm{x} \mathrm{g}$ for $15 \mathrm{~min}$. Beads were then washed with lysis buffer and centrifugation was repeated three times. The immunoprecipitated protein complexes were analyzed via western blotting.

Statistical analysis. Statistical analysis was performed using SPSS 20.0 software (IBM Corp.). Differences between groups were compared using one-way ANOVA followed by Tukey's post hoc test. $\mathrm{P}<0.05$ was considered to indicate a statistically significant difference. In total, three duplicated experiment were performed.

\section{Results}

Res cells resist PTX-induced senescence. To study drug resistance, Res UMUC3 and EJ cells were established via prolonged culture in the presence of cisplatin. As presented in Fig. S1, the selected cells were resistant to cisplatin, as well as PTX. Res cells exhibited normal proliferative profile as demonstrated by results of DNA replication (Fig. 1A), cell cycle distribution (Fig. 1B) and the expression of cell cycle-related proteins, including Cyclin D1, Cyclin E1 and minichromosome maintenance complex component 7 (MCM7) (Fig. 1C). Upon acute PTX treatment, Res cells presented with significantly decreased DNA replication (Fig. 1A) and $G_{1} / G_{0}$ accumulation (Fig. 1B). Moreover, the proteins expression levels of Cyclin D1, Cyclin E1 and MCM7 were significantly decreased (Fig. 1C). These data indicated that the Res cells entered a non-proliferative quiescent state upon PTX stress.

It has been reported that prolonged proliferation arrest could lead to cell senescence (25) and that PTX can induce cell senescence $(16,17)$. In UMUC3 and EJ cells with a 2-day PTX exposure, it was observed that the staining of SA- $\beta-\mathrm{Gal}$ was 20-50 times higher compared with that in cells without PTX treatment (Fig. 1D). Accordingly, the expression levels of the canonical senescence-associated proteins, $\mathrm{p} 53$ and p21, were increased after PTX treatment; however, p53 expression demonstrated no statistical difference after PTX treatment in EJ cells (Fig. 1E). While UMUC3 cells carry a homozygous tumor protein p53 mutation, it has been revealed that p53 function still remains in UMUC3 cells (26). However, in the UMUC3 Res and EJ Res cells, nearly no SA- $\beta-G a l$ positive signals were detected after PTX treatment (Fig. 1D). Consistently, p53 protein expression was decreased in PTX-treated Res cells (Fig. 1E). p21 expression was also decreased in EJ Res cells, but increased in the UMUC3 Res cells, indicating the discrepancy between the different cell types (Fig. 1E). According to the ATCC and a previous report, the cyclin dependent kinase inhibitor $2 \mathrm{~A}$ (cdkn2a), a gene encoding p16 protein, is mutated or deleted in UMUC3 and EJ cells $(27,28)$. Consistent with this, no p16 protein was detected in both cell lines (data not shown). These results demonstrated that the Res cells appeared to escape from senescence and remained in a quiescent state under PTX stress.

Res cells enter quiescence with prolonged circadian rhythm. The circadian rhythm is closely associated with cell proliferation (29), and also regulates cell senescence (30). The expression levels of the core circadian genes, BMAL1, CLOCK, PER2 and CRY1, were detected in the Res cells. The mRNA expression levels of the four core circadian genes fluctuated over a period of $24 \mathrm{~h}$, similar with those in the parental cells (Fig. 2A). However, the circadian oscillation was disturbed after PTX treatment demonstrated by an increased amplitude and a prolonged period in the Res cells. In the UMUC3 Res cells, the circadian period was $\sim 48 \mathrm{~h}$, and in the EJ Res cells circadian oscillation was not noticed in a period of $48 \mathrm{~h}$ (Fig. 2A). Moreover, the expression of the circadian genes at the protein level showed similar oscillation before and after PTX treatment. However, the amplitude of CRY1 oscillation was reduced by PTX in both UMUC3 Res (Fig. 2B) and EJ Res cells (Fig. S2).

To further clarify the relationship between the circadian rhythm and cell proliferation, the expression levels of circadian gene were examined in serum-starved cells. As expected, 

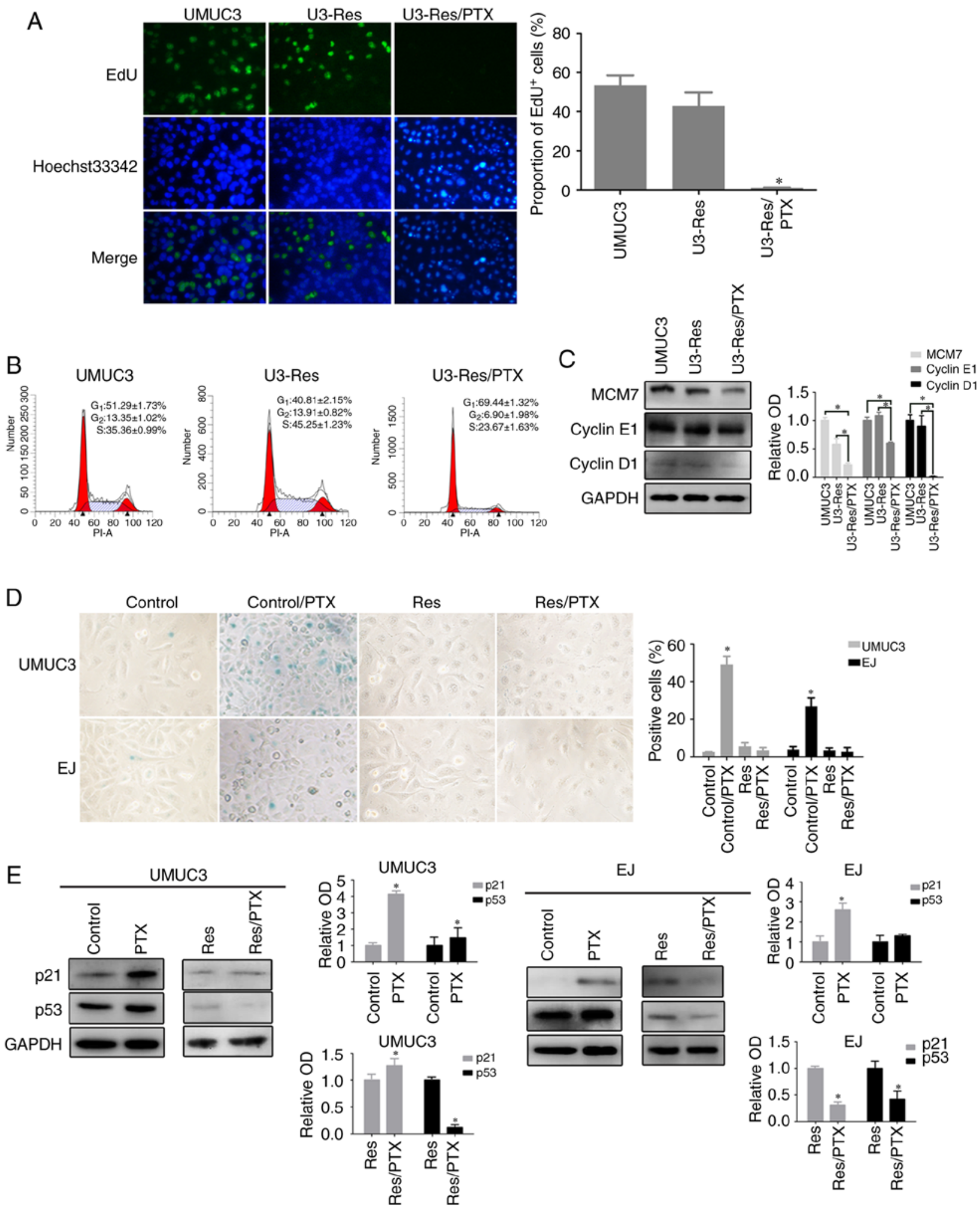

EJ
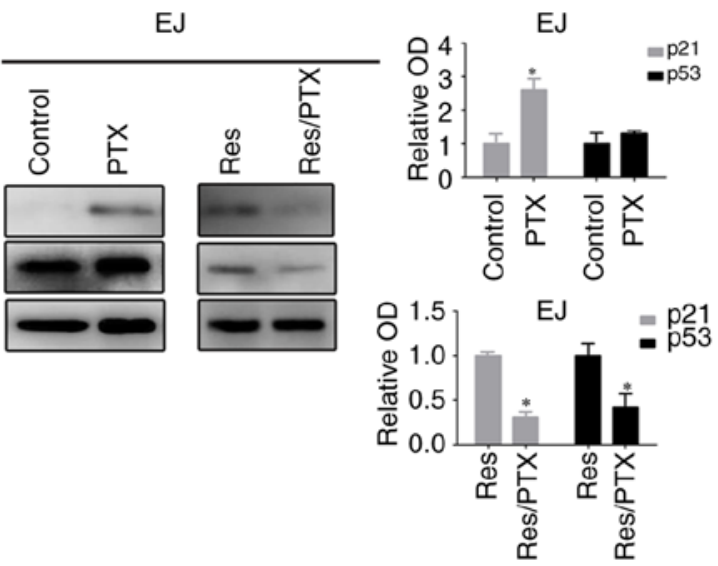

Figure 1. Drug-resistant cells enter into a non-proliferative state and escape from senescence. Res cells were treated with PTX (80 nM) for 3 days. (A) Cell proliferation was detected using an EdU incorporation assay (magnification, $\mathrm{x} 400$ ). Data are presented as the mean \pm SD of three independent experiments. ${ }^{*} \mathrm{P}<0.05$ vs. U3-Res. (B) Cell cycle were analyzed via fluorescence-activated cell sorting flow cytometry. (C) Expression levels of Cyclin D1, Cycline E1 and MCM7 were detected via western blot analysis. Data are presented as the OD fold difference related to the control from three duplicate experiments. ${ }^{*} \mathrm{P}<0$.05. (D) Representative images of senescence-associated $\beta$-galactosidase staining of cells with or without PTX (magnification, $x 400$ ). Data are presented as the mean \pm SD of three independent experiments. ${ }^{*} \mathrm{P}<0.05$ vs. control. (E) Expression levels of p53 and p21 were detected using western blotting, GAPDH was used as loading control. Data are presented as the OD fold difference related to the control from three duplicate experiments. " $\mathrm{P}<0.05$ vs. control. Res, cisplatin-resistant cells; PTX, paclitaxel; EdU, 5-ethynyl-2'-deoxyuridine; OD, optical density; MCM7, minichromosome maintenance complex component 7.

serum starvation induced a prolonged circadian oscillation (Fig. S3). These results indicated that the quiescent status of
PTX-treated Res cells was accompanied with a prolonged circadian rhythm. 
A
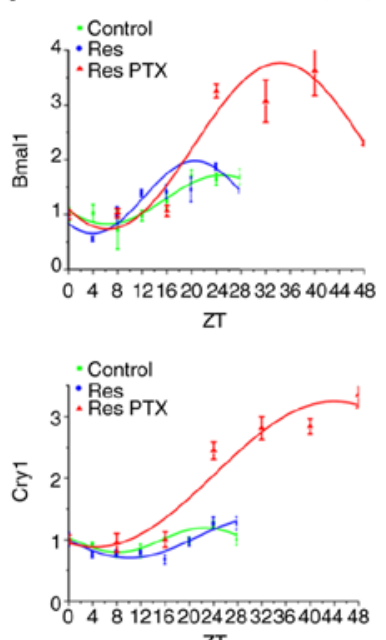

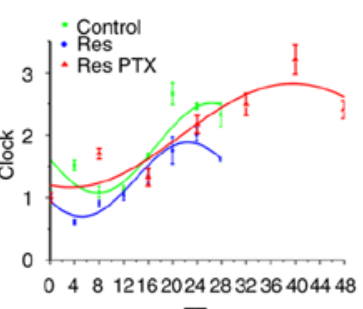

ZT

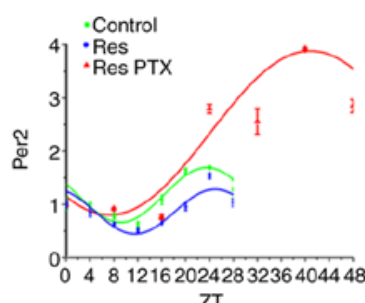

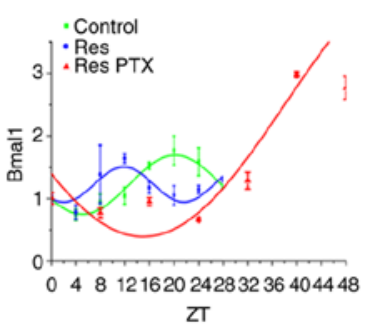
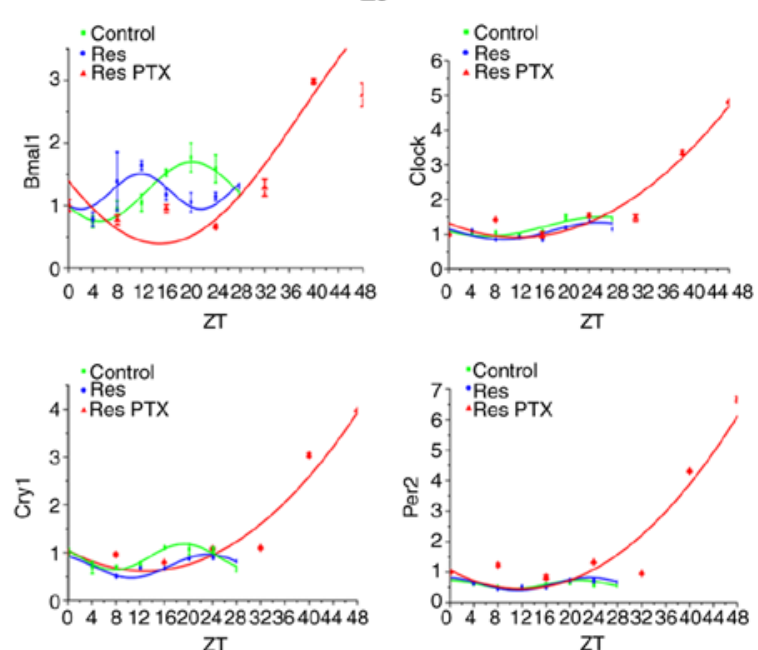

U3-Res/PTX

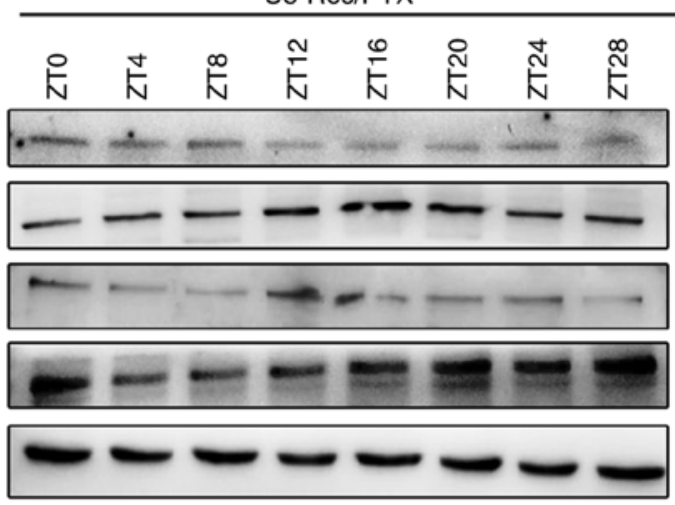

U3-Res/PTX
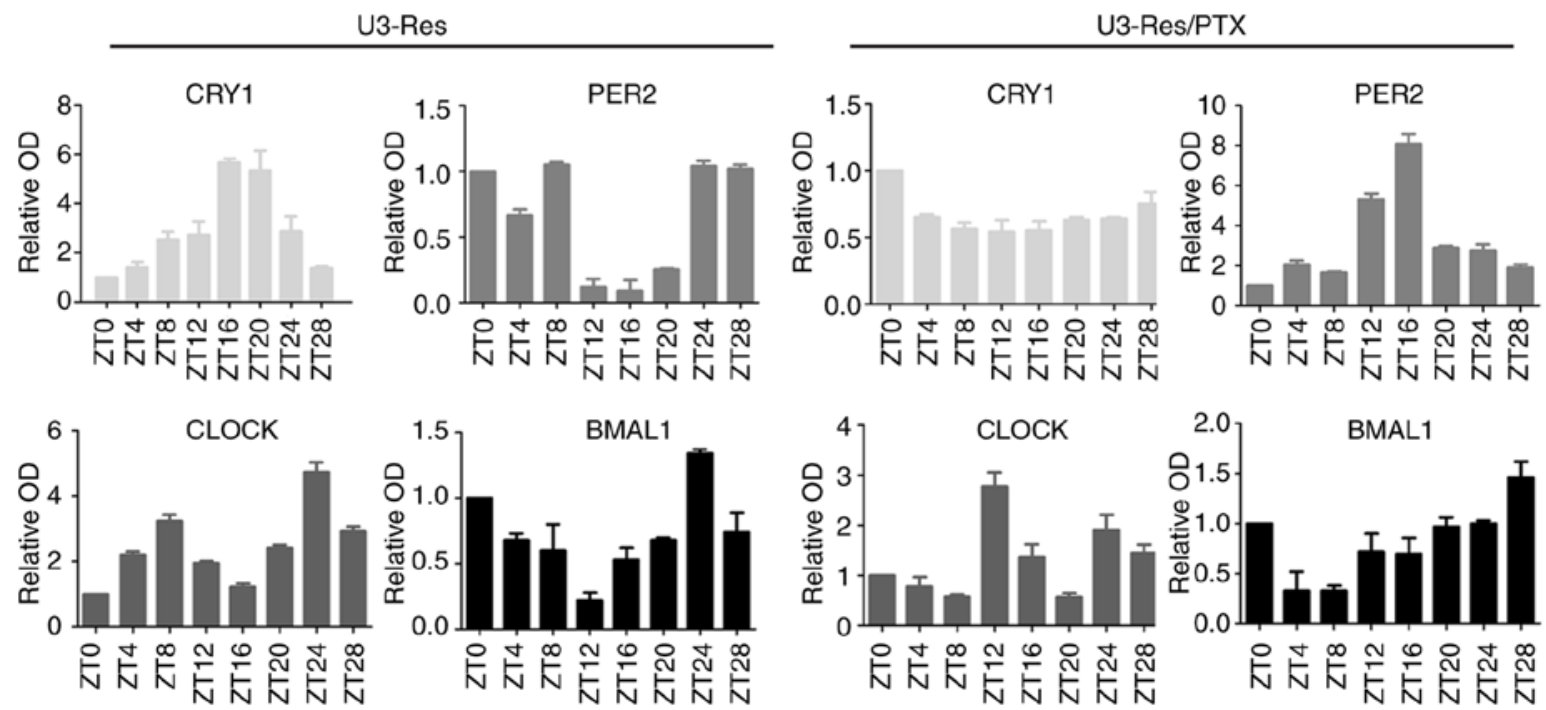

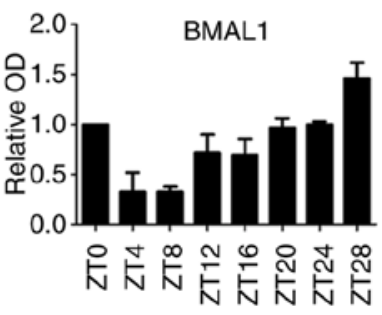

Figure 2. Res cells enter quiescence with prolonged circadian period. After cells (UMUC3 and EJ, Res and Res + PTX) were synchronized with $0.1 \mu$ M dexamethasone for $2 \mathrm{~h}$, circadian genes were detected at different time points. (A) mRNA expression levels of circadian clock genes (BMAL1, CLOCK, PER2 and CRY1) and corresponding fitted cosinor curves. (B) Time course of protein (BMAL1, CLOCK, PER2 and CRY1) expression levels in the Res and Res + PTX $(80 \mathrm{nM})$ cells. $\beta$-Actin was used as loading control. Data are presented as the OD fold difference related to the control from three duplicate experiments. Res, cisplatin-resistant cells; PTX, paclitaxel; OD, optical density; ZT, circadian time; CRY1, Cryptochrome 1; PER2, period 2; CLOCK, circadian locomotor output cycles kaput; BMAL1, brain and muscle Arnt-like protein 1.

CRY1 is accumulated in Res cells after PTX treatment. Next, the expression levels of the four circadian proteins were compared in the parental, Res and Res + PTX cells.
In UMUC3 cells, BMAL1, CLOCK and PER2 expression levels were decreased in the Res and Res + PTX cells compared with parental UMUC3 cells, but there was no 

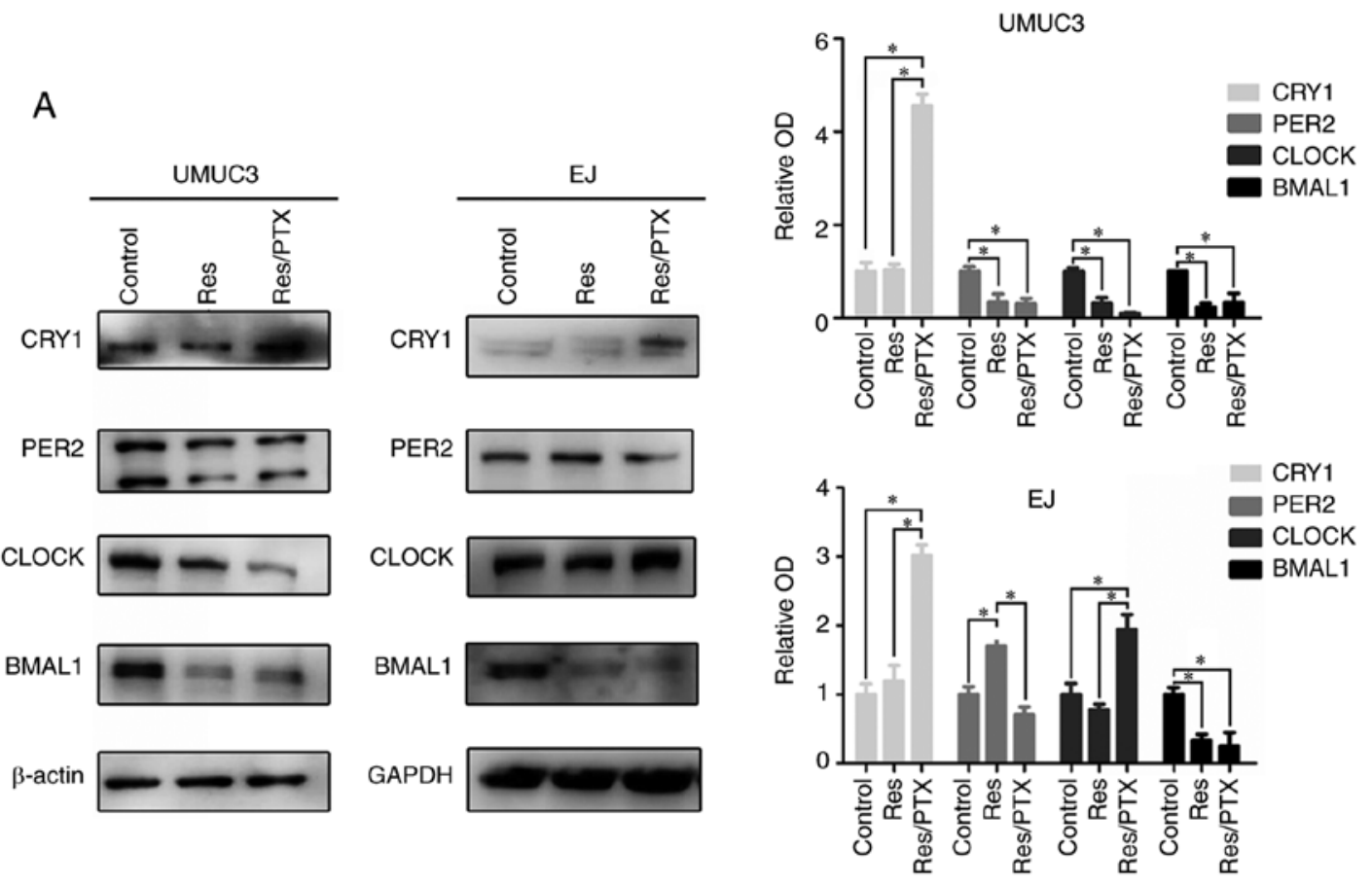

B

UMUC3
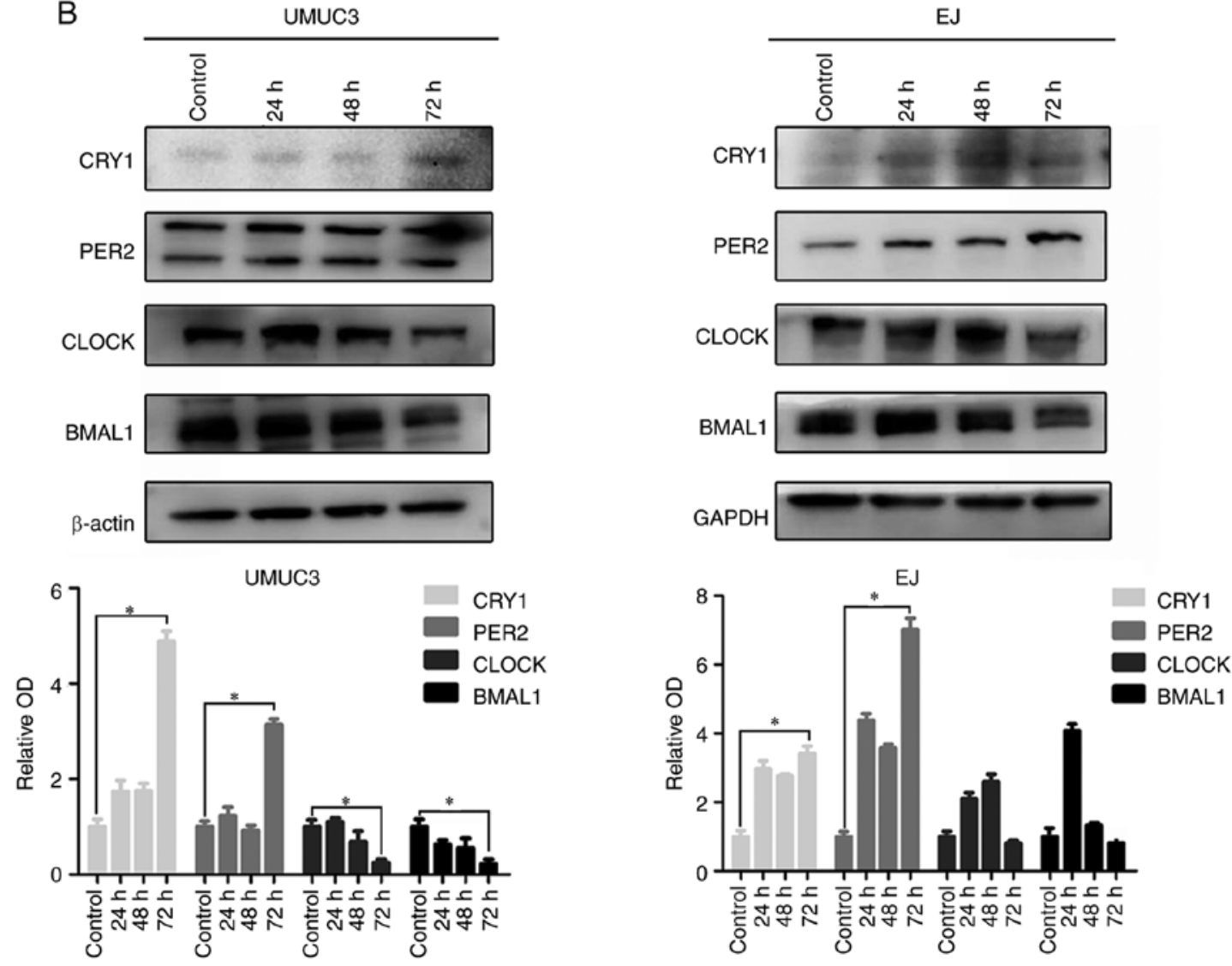

Figure 3. Expression levels of circadian clock proteins in the Res cells with PTX treatment. (A) Total extracts of cells were harvested at $2 \mathrm{~h}$ post-dexamethasone $(0.1 \mu \mathrm{M})$. The expression levels of $\beta$-Actin and circadian clock proteins, including BMAL1, CLOCK, PER2 and CRY1, were assessed via western blot analysis. (B) EJ and UMUC3 cells were treated with serum-free medium for 24, 48 and $72 \mathrm{~h}$. The expression levels of BMAL1, CLOCK, PER2 and CRY1 were detected using western blotting. Data are presented as the OD fold difference related to the control from three duplicate experiments. "P $<0.05$. CRY1, Cryptochrome 1; PER2, period 2; CLOCK, circadian locomotor output cycles kaput; BMAL1, brain and muscle Arnt-like protein 1; Res, cisplatin-resistant cells; PTX, paclitaxel; OD, optical density.

significant difference between Res and Res + PTX cells. Noticeably, CRY1 protein was significantly increased in the Res + PTX cells (Fig. 3A). In EJ cells, CRY1 and
BMAL1 demonstrated similar trends as in UMUC3 cells. PER2 expression increased in the Res cells compared with control and Res + PTX cells. CLOCK expression 
A
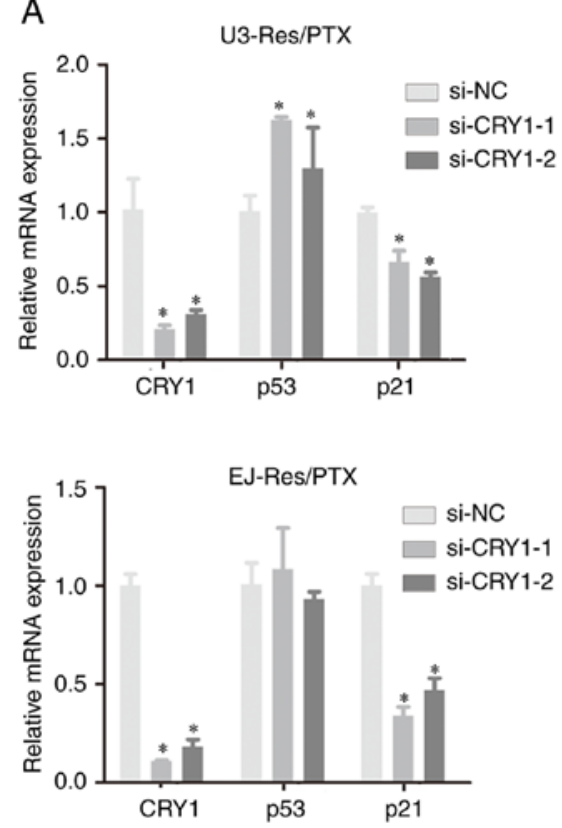

B

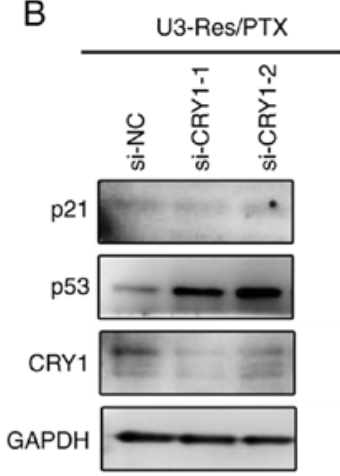

UMUC3

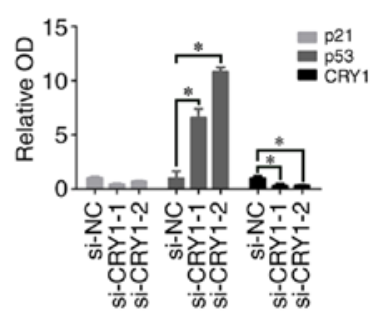

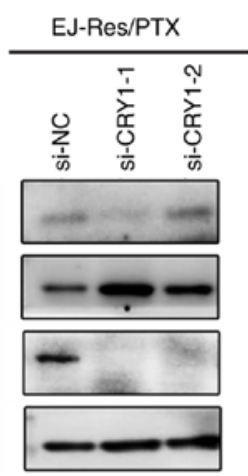

EJ

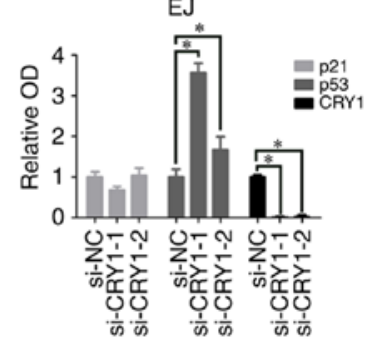

C
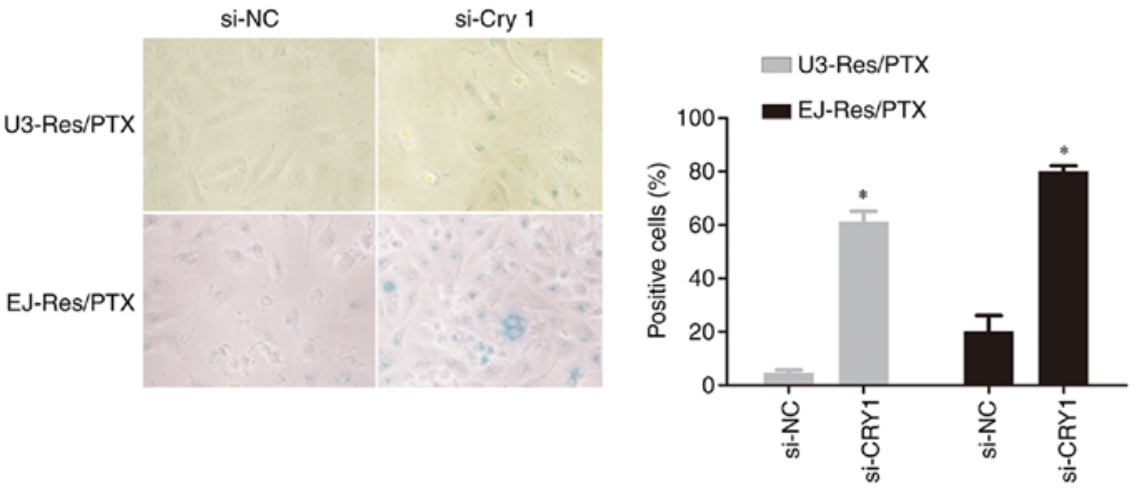

D
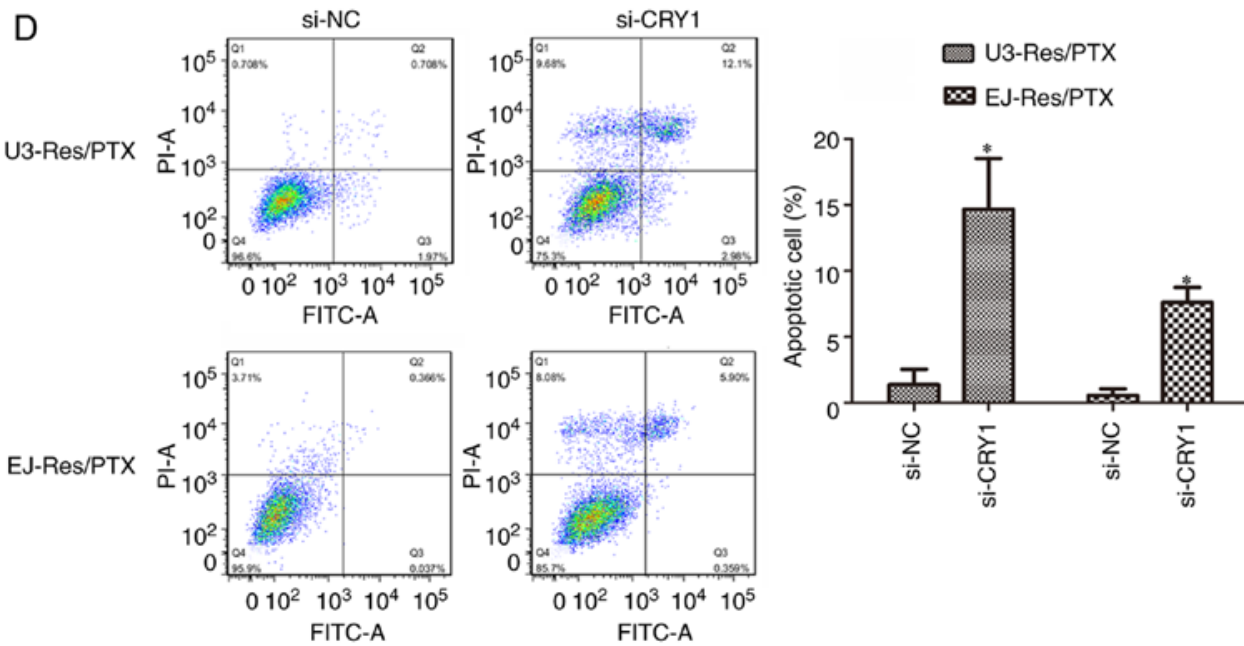

Figure 4. CRY1 knockdown increases PTX-induced senescence. Res cells with prolonged PTX treatment were used as a cell model. Cells were transfected with CRY1 siRNA or si-NC for 48 h. (A) mRNA expression levels of CRY1, p53 and p21 were examined using reverse transcription-quantitative PCR. Data are presented as the mean \pm SD of three independent experiments. ${ }^{*} \mathrm{P}<0.05$. (B) Protein expression levels of CRY1, p53 and p21 were examined via western blotting. Data are presented as the OD fold difference related to GAPDH. * $\mathrm{P}<0.05$. (C) Representative images of senescence-associated $\beta$-galactosidase staining of cells with or without Cryl knockdown (magnification, $\mathrm{x} 400$ ). Data are presented as the mean \pm SD of three independent experiments. $\mathrm{P}<0.05$. (D) Cell apoptosis was detected using fluorescence-activated cell sorting flow cytometry. Data are presented as the mean \pm SD of three independent experiments. ${ }^{*}<0.05$. si-NC, negative control siRNA; Res, cisplatin-resistant cells; PTX, paclitaxel; OD, optical density; CRY1, Cryptochrome 1; siRNA, small interfering RNA.

was significantly increased in the Res + PTX group vs. Control and Res groups (Fig. 3A). The circadian proteins were further compared in the serum-starvation cells. After starvation for $72 \mathrm{~h}, \mathrm{CRY} 1$ and PER2 accumulated significantly in both cell lines. Moreover, CLOCK and BMAL1 expression levels decreased in UMUC-3 cells, but there 

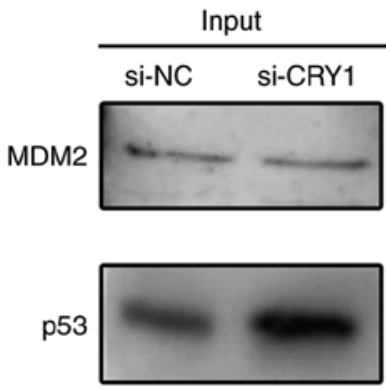

CRY1

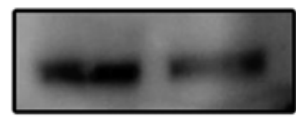

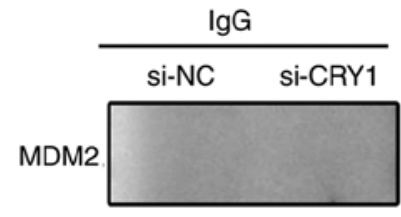

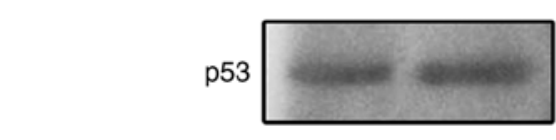

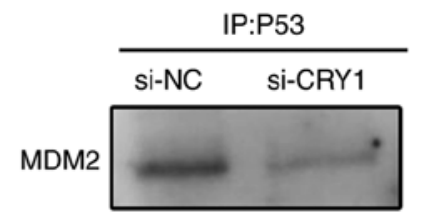

GAPDH
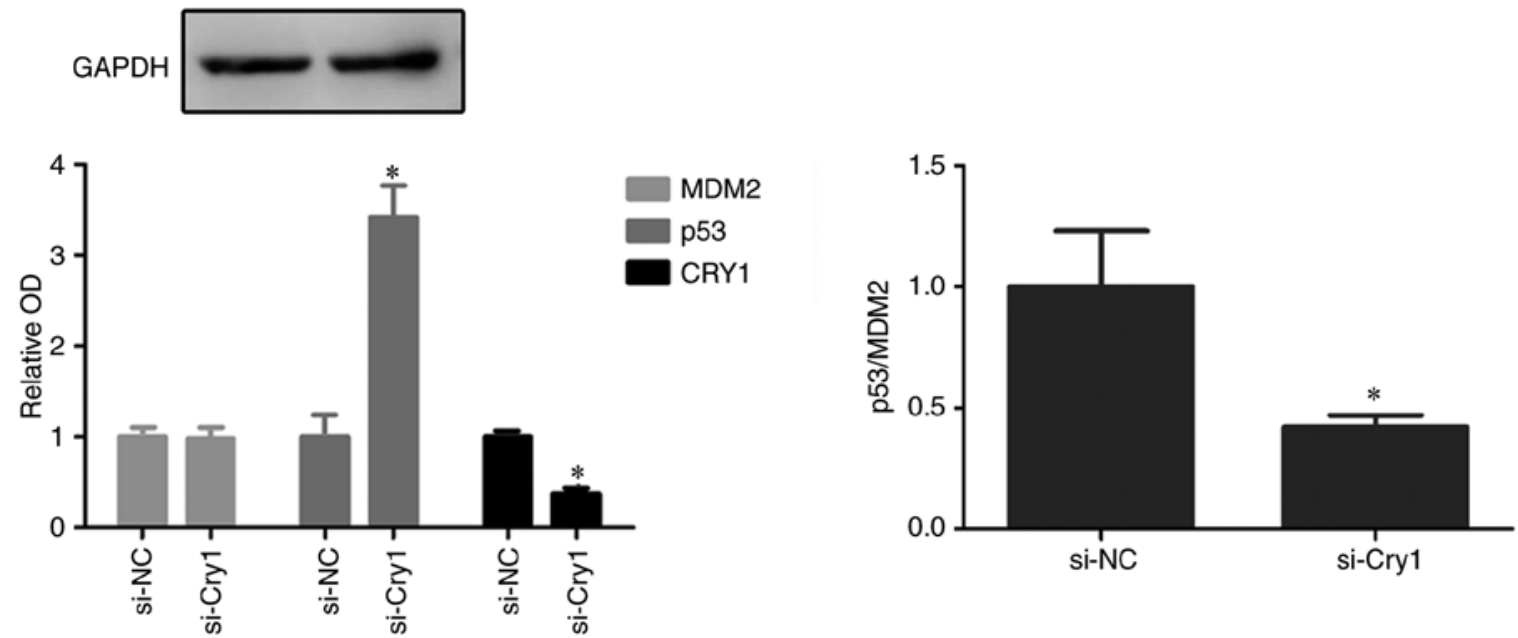

Figure 5. CRY1 promotes MDM2-mediated p53 degradation. EJ-Res cells were transfected with CRY1 siRNA or si-NC for $48 \mathrm{~h}$. Total cell lysates were subjected to co-immunoprecipitation with an anti-p53 antibody followed by western blotting with MDM2 antibodies. Data are presented as the OD fold difference related to control. ${ }^{*} \mathrm{P}<0.05$. si-NC, negative control siRNA; Res, cisplatin-resistant cells; PTX, paclitaxel; OD, optical density; CRY1, Cryptochrome 1; siRNA, small interfering RNA; IP, immunoprecipitation; MDM2, MDM2 proto-oncogene.

were no significant changes in EJ cells after serum-starvation for $72 \mathrm{~h}$ (Fig. 3B).

CRY1 knockdown induces senescence in Res cells after PTX treatment. It was further examined whether CRY1 functioned as an inhibitor in PTX-induced senescence. To test this, siRNA was used to knockdown CRY1 expression in the PTX-treated Res cells.(Fig. 4A and B). After CRY1 knockdown, p21 mRNA expression was significantly downregulated (Fig. 4A), but its protein expression was not significantly changed in both Res cells (Fig. 4B). The p53 mRNA expression did not change significantly in EJ Res cells, but was significantly increased in UMUC3 Res cells (Fig. 4A). Moreover, its protein expression was significantly enhanced after CRY1 knockdown in both cell lines (Fig. 4B). The si-CRY1-1 demonstrated a higher efficiency compared with the si-CRY1-2 to inhibit CRY1 expression. Therefore, the si-CRY1-1 was used in subsequent experiments. It was identified that CRY1 knockdown induced apparent senescence in the PTX-treated Res cells (Fig. 4C). Furthermore, apoptosis was significantly enhanced in the PTX-treated Res cells by CRY1 knockdown (Fig. 4D). These results indicated that CRY1 contributed to resistance of senescence by decreasing p53 protein expression.
CRY1 promotes MDM2 proto-oncogene (MDM2)-mediated p53 degradation. The E3 ubiquitin ligase MDM2 mediates p53 ubiquitination, leading to p53 degradation, which is the major mechanism for p53 protein turnover (31) Since CRY1 knockdown increased the expression of p53 protein, but not p53 mRNA, it was investigated whether CRY1 participated in MDM2-mediated p53 degradation in the Res cells. The Co-IP assay using anti-p53 antibody successfully detected an interaction between endogenous MDM2 and p53 proteins. It was found that CRY1 knockdown significantly decreased MDM2 expression in the immunoprecipitation complex (Fig. 5), suggesting that the MDM2/p53 interaction was attenuated by CRY1 knockdown. This indicated that CRY1 could facilitate the interaction of p53 with MDM2 and potentiate p53 degradation.

\section{Discussion}

Cellular quiescence or dormancy is an evolutionary conserved mechanism of survival, which helps cells adapt to stress and survive a hostile environment (32). Glioblastoma cells can enter a quiescent state to acquire survival advantages and ultimately chemoresistance $(33,34)$. Fluorouracil (5FU)-resistant human colon cancer cells will enter a reversible quiescent $\mathrm{G} 0$-state 
upon re-exposure to higher 5FU concentrations (35). Our previous research revealed that cancer cells enter quiescence in acidic extracellular culture (36). In the current study, when the Res BC cells were treated with higher PTX, cells were arrested at $G_{1} / G_{0}$, DNA replication was markedly inhibited and, more importantly, the expression levels of $\mathrm{G}_{1}-\mathrm{S}$ cyclin proteins (Cyclin D1 and E1) were significantly decreased. Therefore, entering quiescence is an effective mechanism for tumor cells to resist chemotherapy and radiation in various types of cancer, and present as an important mechanism of drug-resistance (37).

The present study identified a prolonged circadian rhythm in quiescent cells, including PTX-treated Res cells and serum-starved cells. Furthermore, CRY1 protein expression was found to be increased in quiescent cells. CRY1 is a core clock repressor that, along with PER, determines circadian periodicity (38), and stabilization of CRY1 prolongs the circadian rhythm (39). Therefore, the prolonged circadian rhythm may due to the accumulation of CRY1 protein. It has been revealed that disruption of the circadian rhythm could drive intrinsic resistance to anticancer drugs, including PTX (40), Doxorubicin (41) and tamoxifen (42). More specifically, circadian proteins are reported to regulate drug resistance. The gene timeless circadian regulator confers cisplatin resistance and could represent a valuable prognostic factor in nasopharyngeal carcinoma (43). CLOCK regulates the expression of Tip60 and contributes to cisplatin resistance (44). KS15, an inhibitor of CRY, decreases the speed of cell proliferation and increases the sensitivity of MCF-7 cells to doxorubicin and tamoxifen (45). These results confirm a close association between the circadian rhythm and drug resistance.

TIS is gaining increased attention in anticancer therapy $(46,47)$. The present study demonstrated that PTX induced apparent senescence in BC cells, but not in the Res cells. Since these Res cells were arrested in $G_{1} / G_{0}$ phase under PTX stress, it is of great important to investigate how these cells escape from senescence. It was identified that the circadian protein CRY1 was accumulated in these Res cells and, more importantly, CRY1 knockdown could restore the ability of PTX to induce senescence. The current results indicated that the accumulation of CRY1 protected BC cells against PTX-induced senescence. On the contrary, it has been reported that in mouse embryonic fibroblasts CRY1/2 functions as an inducer of oncogene-induced senescence by suppressing the activating transcription factor 4 , a potent repressor of p16 and p19 (also known as p14 in humans) (48). However, this pathway may not function in BC cells, as cdkn2a (the gene encoding p16 protein) is mutated or missing in these cells (27). Moreover, such a controversial phenotype may be explained by a different type of senescence, such as therapy-vs. oncogene-induced senescence. The difference between healthy fibroblasts and tumor cells may also lead to different results (49). Other circadian proteins have been shown to regulate cell senescence. For instance, BMAL1KO mice present signs of epidermal stem cells ageing, which is accompanied by increased expression of p16 (50), while CLOCK mutant mice have an accelerated aging program at low-dose irradiation (51). Collectively, these results highlight the existence of a complex interconnection between senescence and individual components of the circadian clock machinery.
The present study identified that CRY1 knockdown increased p53 protein expression without changing p53 mRNA level, indicating that CRY1 promoted p53 degradation. Furthermore, it was demonstrated that CRY1 facilitated the interaction of p53 with MDM2, contributing to p53 degradation. Consistently, it has been reported previously that CRY1 could promote FOXO1 degradation by promoting FOXO1 binding to the ubiquitin E3 ligase MDM2 (31). Thus, it is suggested that CRY1 acts as a coordinator with MDM2. Similarly, another cryptochrome protein, CRY2, has been identified as a component of F-box and leucine rich repeat protein 3-containing E3 ligase that recruits c-MYC for ubiquitination $(52,53)$. In addition, CRY1 can interact with the glucocorticoid receptor and widely alter the transcriptional response to glucocorticoids in mouse embryonic fibroblasts (54). CRY can also increase insulin-like growth factor transcription by promoting JAK2-dependent STAT5 phosphorylation (55). Taken together, these findings suggested that, as a clock repressor, CRY1 also functioned to connect circadian rhythms with multiple other physiological or pathological processes.

In conclusion, the present study demonstrated an inhibitory effect of CRY1 on PTX-induced cellular senescence in BC. Thus, targeting CRY1 may be a feasible strategy to induce senescence in cancer cells. However, the present study was limited to PTX-induced senescence in BC, and it is important to investigate whether CRY1 has similar anti-senescence function in other types of cancer cells, and whether CRY1 still functions in other types of senescence.

\section{Acknowledgements}

The authors would like to thank Dr Junfang Ji (Zhejiang University) and Dr Ziyi Wang (Zhejiang University) for improving the English writing of this article.

\section{Funding}

This work was supported by the grants from the Shenzhen Science and Technology Project (grant nos. JCYJ20180305 164655077 and JCYJ20180305124227251) and the National Natural Science Foundation of China (grant no. 81672915).

\section{Availability of data and materials}

The datasets used and/or analyzed during the current study are available from the corresponding author on reasonable request.

\section{Authors' contributions}

JL and XL designed the experiments. MJ, BS, LM, WQ, JY, PL and BY performed the experiments. MJ, DL, DW, LX, HL and $\mathrm{ZZ}$ analyzed the experimental results. JL and MJ wrote the manuscript. All authors reviewed the manuscript, and have read and approved the final manuscript.

\section{Ethics approval and consent to participate}

Not applicable. 


\section{Patient consent for publication}

Not applicable.

\section{Competing interests}

The authors declare that they have no competing interests.

\section{References}

1. Casadei C, Dizman N, Schepisi G, Cursano MC, Basso U, Santini D, Pal SK and De Giorgi U: Targeted therapies for advanced bladder cancer: New strategies with FGFR inhibitors. Ther Adv Med Oncol 11: 1758835919890285, 2019.

2. Alfred Witjes J,Lebret T, Compérat EM, Cowan NC, De Santis M, Bruins HM, Hernández V, Espinós EL, Dunn J, Rouanne M, et al Updated 2016 EAU guidelines on muscle-invasive and metastatic bladder cancer. Eur Urol 71: 462-475, 2017.

3. Ke B, Wei T, Huang Y, Gong Y, Wu G, Liu J, Chen X and Shi L: Interleukin-7 resensitizes non-small-cell lung cancer to cisplatin via inhibition of ABCG2. Mediators Inflamm 2019: 7241418 , 2019.

4. Wang Y, Li LJ, Qiu MX and Gong BS: Effects of paclitaxel combined with miR-448 on growth and proliferation of bladder cancer EJ cells. Eur Rev Med Pharmacol Sci 22: 3363-3369, 2018

5. Zeng Q, Liu J, Cao P, Li J, Liu X, Fan X, Liu L, Cheng Y, Xiong W, Li J, et al: Inhibition of REDD1 sensitizes bladder urothelial carcinoma to paclitaxel by inhibiting autophagy. Clin Cancer Res 24: 445-459, 2018.

6. He Q, Li J, Yin W, Song Z, Zhang Z, Yi T, Tang J, Wu D, Lu Y, Wang Z, et al: Low-dose paclitaxel enhances the anti-tumor efficacy of GM-CSF surface-modified whole-tumor-cell vaccine in mouse model of prostate cancer. Cancer Immunol Immunother 60: 715-730, 2011.

7. Michaelson MD, Hu C, Pham HT, Dahl DM, Lee-Wu C, Swanson GP, Vuky J, Lee RJ, Souhami L, Chang B, et al: A phase $1 / 2$ trial of a combination of paclitaxel and trastuzumab with daily irradiation or paclitaxel alone with daily irradiation after transurethral surgery for noncystectomy candidates with muscle-invasive bladder cancer (Trial NRG Oncology RTOG 0524). Int J Radiat Oncol Biol Phys 97: 995-1001, 2017.

8. Albers P, Park SI, Niegisch G, Fechner G, Steiner U, Lehmann J, Heimbach D, Heidenreich A, Fimmers R and Siener R; AUO Bladder Cancer Group: Randomized phase III trial of 2nd line gemcitabine and paclitaxel chemotherapy in patients with advanced bladder cancer: Short-term versus prolonged treatment [German association of urological oncology (AUO) trial AB 20/99]. Ann Oncol 22: 288-294, 2011.

9. Mari A, D'Andrea D, Abufaraj M, Foerster B, Kimura S and Shariat SF: Genetic determinants for chemo- and radiotherapy resistance in bladder cancer. Transl Androl Urol 6: 1081-1089, 2017.

10. Zhao YH, Qin XL, Yang JY, Liao YW, Wu XZ and Zheng HP: Identification and expression analysis of ceftriaxone resistance-related genes in Neisseria gonorrhoeae integrating RNA-Seq data and qRT-PCR validation. J Glob Antimicrob Resist 16: 202-209, 2019.

11. Kang S, Xie J, Miao J, Li R, Liao W and Luo R: A knockdown of Maml1 that results in melanoma cell senescence promotes an innate and adaptive immune response. Cancer Immunol Immunother 62: 183-190, 2013.

12. Mikula-Pietrasik J, Niklas A, Uruski P, Tykarski A and Książek K: Mechanisms and significance of therapy-induced and spontaneous senescence of cancer cells. Cell Mol Life Sci 77: 213-229, 2020.

13. Collado $\mathbf{M}$ and Serrano M: Senescence in tumours: Evidence from mice and humans. Nat Rev Cancer 10: 51-57, 2010.

14. Lee $S$ and Lee JS: Cellular senescence: A promising strategy for cancer therapy. BMB Rep 52: 35-41, 2019.

15. Qin S, Schulte BA and Wang GY: Role of senescence induction in cancer treatment. World J Clin Oncol 9: 180-187, 2018

16. Khongkow P, Gomes AR, Gong C, Man EP, Tsang JW, Zhao F, Monteiro LJ, Coombes RC, Medema RH, Khoo US and Lam EW: Paclitaxel targets FOXM1 to regulate KIF20A in mitotic catastrophe and breast cancer paclitaxel resistance. Oncogene 35: 990-1002, 2016.
17. Kavanagh EL, Lindsay S, Halasz M, Gubbins LC, Weiner-Gorzel K, Guang MHZ, McGoldrick A, Collins E, Henry M, Blanco-Fernández A, et al: Protein and chemotherapy profiling of extracellular vesicles harvested from therapeutic induced senescent triple negative breast cancer cells. Oncogenesis 6: e388, 2017.

18. Baba K and Tosini G: Aging alters circadian rhythms in the mouse eye. J Biol Rhythms 33: 441-445, 2018.

19. Rakshit K, Wambua R, Giebultowicz TM and Giebultowicz JM: Effects of exercise on circadian rhythms and mobility in aging Drosophila melanogaster. Exp Gerontol 48: 1260-1265, 2013.

20. Takahashi JS: Transcriptional architecture of the mammalian circadian clock. Nat Rev Genet 18: 164-179, 2017.

21. Relles D, Sendecki J, Chipitsyna G, Hyslop T, Yeo CJ and Arafat HA: Circadian gene expression and clinicopathologic correlates in pancreatic cancer. J Gastrointest Surg 17: 443-450, 2013.

22. Taniguchi H, Fernández AF, Setién F, Ropero S, Ballestar E, Villanueva A, Yamamoto H, Imai K, Shinomura Y and Esteller M: Epigenetic inactivation of the circadian clock gene BMAL1 in hematologic malignancies. Cancer Res 69: 8447-8454, 2009.

23. Zhu Y, Stevens RG, Hoffman AE, Fitzgerald LM, Kwon EM, Ostrander EA, Davis S, Zheng T and Stanford JL: Testing the circadian gene hypothesis in prostate cancer: A population-based case-control study. Cancer Res 69: 9315-9322, 2009.

24. Livak KJ and Schmittgen TD: Analysis of relative gene expression data using real-time quantitative PCR and the 2(-Delta Delta C(T)) method. Methods 25: 402-408, 2001.

25. Terzi MY, Izmirli M and Gogebakan B: The cell fate: Senescence or quiescence. Mol Biol Rep 43: 1213-1220, 2016.

26. Yang L, Li Y, Bhattacharya A and Zhang Y: PEPD is a pivotal regulator of p53 tumor suppressor. Nat Commun 8: 2052, 2017.

27. Grim J, D'Amico A, Frizelle S, Zhou J, Kratzke RA and Curiel DT: Adenovirus-mediated delivery of p16 to p16-deficient human bladder cancer cells confers chemoresistance to cisplatin and paclitaxel. Clin Cancer Res 3: 2415-2423, 1997.

28. Sanchez-Carbayo M, Socci ND, Charytonowicz E, Lu M, Prystowsky M, Childs G and Cordon-Cardo C: Molecular profiling of bladder cancer using cDNA microarrays: Defining histogenesis and biological phenotypes. Cancer Res 62: 6973-6980, 2002.

29. Gaucher J, Montellier E and Sassone-Corsi P: Molecular cogs: Interplay between circadian clock and cell cycle. Trends Cell Biol 28: 368-379, 2018.

30. Sulli G, Rommel A, Wang X, Kolar MJ, Puca F, Saghatelian A, Plikus MV, Verma IM and Panda S: Pharmacological activation of REV-ERBs is lethal in cancer and oncogene-induced senescence. Nature 553: 351-355, 2018.

31. Jang H, Lee GY, Selby CP, Lee G, Jeon YG, Lee JH, Cheng KK, Titchenell P, Birnbaum MJ, Xu A, et al: SREBP1c-CRY1 signalling represses hepatic glucose production by promoting FOXO1 degradation during refeeding. Nat Commun 7: 12180, 2016.

32. Manjili MH: Tumor dormancy and relapse: From a natural byproduct of evolution to a disease state. Cancer Res 77: 2564-2569, 2017.

33. Wang L, Shang Z, Zhou Y, Hu X, Chen Y, Fan Y, Wei X, Wu L, Liang Q, Zhang J and Gao Z: Autophagy mediates glucose starvation-induced glioblastoma cell quiescence and chemoresistance through coordinating cell metabolism, cell cycle, and survival. Cell Death Dis 9: 213, 2018.

34. Atkins RJ, Stylli SS, Kurganovs N, Mangiola S, Nowell CJ, Ware TM, Corcoran NM, Brown DV, Kaye AH, Morokoff A, et al: Cell quiescence correlates with enhanced glioblastoma cell invasion and cytotoxic resistance. Exp Cell Res 374: 353-364, 2019.

35. Touil Y, Igoudjil W, Corvaisier M, Dessein AF, Vandomme J, Monté D, Stechly L, Skrypek N, Langlois C, Grard G, et al: Colon cancer cells escape 5FU chemotherapy-induced cell death by entering stemness and quiescence associated with the c-Yes/YAP axis. Clin Cancer Res 20: 837-846, 2014.

36. Zhang YJ, Xu LL, Wang P, Jian H, Shi X, Jia M, Mo L, Hu Z, Li H and Li J: Phenotypic transition of tumor cells between epithelialand mesenchymal-like state during adaptation to acidosis. Cell Cycle 18: 1938-1947, 2019.

37. De Angelis ML, Francescangeli F, La Torre F and Zeuner A: Stem cell plasticity and dormancy in the development of cancer therapy resistance. Front Oncol 9: 626, 2019.

38. Toledo M, Batista-Gonzalez A, Merheb E, Aoun ML, Tarabra E, Feng D, Sarparanta J, Merlo P, Botrè F, Schwartz GJ, et al: Autophagy regulates the liver clock and glucose metabolism by degrading CRY1. Cell Metab 28: 268-281.e4, 2018. 
39. Hirota T, Lee JW, St John PC, Sawa M, Iwaisako K, Noguchi T, Pongsawakul PY, Sonntag T, Welsh DK, Brenner DA, et al: Identification of small molecule activators of cryptochrome. Science 337: 1094-1097, 2012.

40. Xiang S, Dauchy RT, Hoffman AE, Pointer D, Frasch T, Blask DE and Hill SM: Epigenetic inhibition of the tumor suppressor ARHI by light at night-induced circadian melatonin disruption mediates STAT3-driven paclitaxel resistance in breast cancer. J Pineal Res 67: e12586, 2019.

41. Xiang S, Dauchy RT, Hauch A, Mao L, Yuan L, Wren MA, Belancio VP, Mondal D, Frasch T, Blask DE and Hill SM: Doxorubicin resistance in breast cancer is driven by light at night-induced disruption of the circadian melatonin signal. J Pineal Res 59: 60-69, 2015.

42. Dauchy RT, Xiang S, Mao L, Brimer S, Wren MA, Yuan L, Anbalagan M, Hauch A, Frasch T, Rowan BG, et al: Circadian and melatonin disruption by exposure to light at night drives intrinsic resistance to tamoxifen therapy in breast cancer. Cancer Res 74: 4099-4110, 2014.

43. Liu SL, Lin HX, Lin CY, Sun XQ, Ye LP, Qiu F, Wen W, Hua X, Wu XQ, Li J, et al: TIMELESS confers cisplatin resistance in nasopharyngeal carcinoma by activating the $\mathrm{Wnt} / \beta$-catenin signaling pathway and promoting the epithelial mesenchymal transition. Cancer Lett 402: 117-130, 2017.

44. Miyamoto N, Izumi H, Noguchi T, Nakajima Y, Ohmiya Y, Shiota M, Kidani A, Tawara A and Kohno K: Tip60 is regulated by circadian transcription factor clock and is involved in cisplatin resistance. J Biol Chem 283: 18218-18226, 2008.

45. Chun SK, Chung S, Kim HD, Lee JH, Jang J, Kim J, Kim D, Son GH, Oh YJ, Suh YG, et al: A synthetic cryptochrome inhibitor induces anti-proliferative effects and increases chemosensitivity in human breast cancer cells. Biochem Biophys Res Commun 467: 441-446, 2015.

46. Chang BD, Xuan Y, Broude EV, Zhu H, Schott B, Fang J and Roninson IB: Role of p53 and p21waf1/cip1 in senescence-like terminal proliferation arrest induced in human tumor cells by chemotherapeutic drugs. Oncogene 18: 4808-4818, 1999.

47. Chang BD, Broude EV, Dokmanovic M, Zhu H, Ruth A, Xuan Y, Kandel ES, Lausch E, Christov K and Roninson IB: A senescence-like phenotype distinguishes tumor cells that undergo terminal proliferation arrest after exposure to anticancer agents. Cancer Res 59: 3761-3767, 1999.
48. Katamune C, Koyanagi S, Shiromizu S, Matsunaga N, Shimba S, Shibata S and Ohdo S: Different roles of negative and positive components of the circadian clock in oncogene-induced neoplastic transformation. J Biol Chem 291: 10541-10550, 2016.

49. Wyld L, Bellantuono I, Tchkonia T, Morgan J, Turner O, Foss F, George J, Danson S and Kirkland JL: Senescence and cancer: A review of clinical implications of senescence and senotherapies. Cancers (Basel) 12: 2134, 2020.

50. Janich P, Pascual G, Merlos-Suárez A, Batlle E, Ripperger J, Albrecht U, Cheng HY, Obrietan K, Di Croce L and Benitah SA: The circadian molecular clock creates epidermal stem cell heterogeneity. Nature 480: 209-214, 2011.

51. Antoch MP, Gorbacheva VY, Vykhovanets O, Toshkov IA, Kondratov RV, Kondratova AA, Lee C and Nikitin AY: Disruption of the circadian clock due to the Clock mutation has discrete effects on aging and carcinogenesis. Cell Cycle 7: 1197-1204, 2008.

52. Huber AL, Papp SJ, Chan AB, Henriksson E, Jordan SD Kriebs A, Nguyen M, Wallace M, Li Z, Metallo CM and Lamia KA: CRY2 and FBXL3 cooperatively degrade c-MYC. Mol Cell 64: 774-789, 2016.

53. Du H, Jie L, Xu W, Wu Y, Liu T and Li M: A monoclonal antibody against a potential cancer biomarker, human ubiquitinconjugating enzyme E2. Hybridoma (Larchmt) 31: 196-202, 2012 .

54. Lamia KA, Papp SJ, Yu RT, Barish GD, Uhlenhaut NH, Jonker JW, Downes M and Evans RM: Cryptochromes mediate rhythmic repression of the glucocorticoid receptor. Nature 480: 552-556, 2011.

55. Chaudhari A, Gupta R, Patel S, Velingkaar N and Kondratov R: Cryptochromes regulate IGF-1 production and signaling through control of JAK2-dependent STAT5B phosphorylation. Mol Biol Cell 28: 834-842, 2017. 